\title{
Kasvatus monilajiseen empatiaan
}

\author{
$y$ \\ Monilajisessa maailmassa yhden lajin vastuuton käytös \\ vaarantaa koko maapallon kyvyn ylläpitää elämää. \\ Kasvattajien ja kasvatustieteen on löydettävä uudenlaista \\ yhteistyötä, tietoisuutta ja tunnetta monilajisen elämän \\ turvaamiseksi maapallolla.
}

\section{$\mathbf{y}$}

TUTKIN TÄSSÄ ARTIKKELISSA sitä, miksi lihaproteiineihin suhtaudutaan eri tavalla kuin kasvisproteiineihin, ja minkälainen kasvatustiede voi edesauttaa ekologisesti nykyistä kestävämmän tulevaisuuden muodostumista. Ihmiskunnan haaste on löytää keinoja hillitä ympäristöongelmien kasvua.

Yksinkertaisimpia tapoja vaikuttaa ympäristön tilaan on muuttaa ruokavalioita. Ihminen on metsästänyt, kalastanut ja kasvattanut eläimiä ruoakseen tuhansia vuosia. Halu syödä lihaa ja lihan syöminen eivät sinällään ole ympäristöongelmia, vaan haitallista on vallitseva lihateollisuuden mittakaava. Lihateollisuus tuottaa ympäristöongelmia, minkä vuoksi ruokavaliot vaikuttavat maapallon elinkelpoisuuteen (Potts 2016, 17). Ilmastonmuutoksen rajaaminen kahden celsiusasteen nousuun vuoteen 2070 mennessä edellyttää merkittäviä muutoksia esimerkiksi ruokailutottumuksissa. Erityisesti lihakarjan ja maitotuotteiden kulutuksen vähentäminen ovat keskei- siä, kun tavoitellaan ilmastotavoitteita. (Hedenus, Wirsenius \& Johansson 2014, 91.)

Kirjoittamistani on ohjannut ajatus aikalaiskritiikistä. Aikalaiskriittinen kirjoittaminen tarkoittaa ennen kaikkea näkemyksellistä kirjoittamistapaa. Aikalaiskritiikkiä voidaan kirjoittaa suoraan ja sellaisenaan, jolloin se on samalla sekä näkökulma todellisuuteen että kirjoittamistapa. (Suoranta \& Ryynänen 2014, 185.)

Lihansyömisen asettaminen kasvatustieteellisen tutkimuksen kohteeksi kannustaa pohtimaan sitä, millä tavoin minuutta tuotetaan nykyisyydessä. Ruokahalut edustavat arjen toimintaa, jota on kriittisen pedagogin Henry Giroux’n $(1989,126)$ mukaan analysoitava historiallisena, konkreettisena, sosiaalisena, yhteiskunnallisena ja kulttuurisena tekemisenä. Kriittinen pedagogiikka ilmenee artikkelissani aikalaisdiagnostisena eli ideologiakriittisenä tutkimusmenetelmänä, joka kohdistuu ar- 
kisten ruokahalujen purkamiseen ja marginalisoidussa asemassa olevien ihmisten kuuntelemiseen (ks. Suoranta 2005, 21-23). Artikkeli hyödyntää Henry Giroux'n ja Peter McLarenin esimerkkiä lähestymällä yhteiskunnallisia ongelmia monitieteisesti (ks. Suoranta 2005, 89). Vakuuttava aikalaiskritiikki hyötyy laaja-alaisesta teoriapohjasta, koska monimutkaisiin ilmiöihin on harvoin yksiselitteistä vastausta, vaan vastauksen etsiminen edellyttää moniäänistä pohdintaa.

Artikkelissa tuon esille länsimaisen ajattelun tuottamia ekologisesti kestämättömiä käytäntöjä ja ajattelutapoja. Länsimaista ajattelua on ohjannut dualistinen käsitys luonnon ja ihmisyyden välisestä ehdottomasta kahtiajaosta (Rose 2011,9). Ruokahalujen synnyttämien tunteiden tarkastelu tuo puolestaan esille sen, kuinka liha- ja kasvisproteiinien välillä vallitsee jako haluttaviin liharuokiin ja epäilyttäviin kasvisruokiin. Jakolinjan avaaminen auttaa ymmärtämään länsimaisen ajattelun traditioita. Kreikkalainen ja juutalaiskristillinen mytologia ovat olleet keskeisiä, kun dualistisia käsityksiä kehon ja mielen sekä ihmisen ja luonnon välisistä suhteista on kehitelty (Haraway 1990, 246).

Ekofeminismi on 1970-luvulla kehittynyt feminismin haara, joka ei sisällä yhtä teoriaa sukupuolesta ja ympäristöstä vaan viittaa monenlaisiin näkökulmiin. Siinä korostuu ajatus siitä, että globaali eriarvoisuus, ympäristöongelmat, yhteiskunnalliset kysymykset ja sukupuolien välinen eriarvoisuus ovat yhteydessä toisiinsa. (Connell \& Pearse 2014, 102-106.)

Ekofeminismin mukaan tieteellistä ajattelua ovat ohjanneet käsiteparit 'ihminen ja luonto', 'länsimaalaiset ja ei-länsimaalaiset' sekä 'sivistyneet ja sivistymättömät'. Ekofeminismissä tuodaan esille näkemys siitä, että naiset ja luonto ovat yhtä lailla yhteiskunnallisen vallankäytön uhreja. Naisiin ja luontoon kohdistunut alistaminen on nähtävissä länsimaisessa tieteenhistoriassa, joka ilmenee syrjivinä metodologisina periaatteina modernin tieteen ja tiedon historiassa. Tämän vuoksi on unohdettu symbioottinen ja vastavuoroinen ihmisen ja luonnon välinen suhde. Laskelmoiva, taloudellista hyötyä tavoitteleva puhdas järki on ilmennyt suhtautumistapana luontoon ja tutkimustyöhön, jossa bioteknologian avulla tavoi- tellaan mahdollisimman suuria taloudellisia voittoja. (Shiva \& Mies 2014, 47-48.)

Ajoittain kärkevä ekofeministinen analyysi edustaa aikalaiskriittisyyttä, jossa käytetään voimakasta, kiihottavaa tai liikuttavaa kieltä (ks. Suoranta \& Ryynänen 2014, 188). Artikkelini paikoin liikuttavan ja kärkevän aikalaiskriittisyyden tavoite on synnyttää itsekriittistä pohdintaa sekä kulutustottumuksista että kasvatustieteestä ekologisesti kestävämmän maailman puolestapuhujana.

Kasvatustiedettä voidaan kehittää ekologisesti yhä kestävämmäksi hahmottelemalla maailmaa toisenlaisista kosmologioista käsin. Tarkastelen alkuperäiskansojen tapoja hahmottaa maailmaa, ja siten tarjoan länsimaisesta tieteellisestä tiedontuotannosta poikkeavia näkemyksiä ihmiselämän verkottuneisuudesta. Alkuperäiskansojen tietämystä koskevia järjestelmiä on lukuisia, ja ne ovat täynnä eroja, mutta valtaosa niistä näkee ihmisen osana luontoa. (Kincheloe 2011 b, 338.) Olennaista on tunnistaa länsimaisen ajattelun leimallinen kahtiajako, jossa yhteiskunnan tehtäväksi luetaan luonnon hallinta ja kontrollointi (Patel \& Moore 2017, 54).

Ylipäätään kyse on ihmisen suhteesta muihin eläviin olentoihin ja ihmisten tavasta määritellä eläimet itsensä kautta (Chen 2012,90). Tätä asennetta kuvaa ihmistieteellisen eläintutkimuksen perustajiin lukeutuva Vinciane Despret $(2016,57)$, jonka mukaan paviaanien käyttäytymisen tutkimusta on ohjannut ihmisenkaltaistaminen. Paviaanien käyttäytymistä on selitetty pitkään hallinnan ja hierarkioiden avulla, jolloin niiden tutkimus on keskittynyt miesten väliseen voimainkoetteluun. (Despret 2016, 57-58.) Kädellisten tutkimus on esimerkki siitä, kuinka kulttuuriset narratiivit ovat ohjanneet tutkimuksen tekemistä (Haraway 1990, 244).

Purkamalla vallitsevia kertomuksia länsimaisesta erityislaatuisuudesta sekä ajatuksia, tunteita ja toimintaa ohjaavista dualistisista käsitepareista luodaan edellytyksiä kertomuksille, joissa ihmisyys ja elämä maapallolla ovat täynnä erilaisia vuorovaikutussuhteita. Märittelemällä itsensä uudella tavalla ihmiset voivat muodostaa uudenlaisia vuorovaikutussuhteita, joiden avulla muovata toimintamallejaan ja näkemyksiään maailmasta (Kincheloe 2011b, 347). 
MaskulitinisuUteEN

YHDISTETTY HALU SYÖD $\ddot{A}$

LIHAA PIT $\ddot{A} \ddot{A}$ YLL $\ddot{A}$ TUNTEITA

LIHA- JA KASVISPROTEIINIEN

ERIARVOISUUDESTA.

Samalla on luotava uudenlaisia kertomuksia ihmisyydestä, sillä kuten feministitutkija Sara Ahmed $(2014,1)$ toteaa, kertomukset synnyttävät tunteita, joiden avulla määritellään meitä ja heitä.

Tunneteorioista on kirjoitettu paljon, mutta vähäisemmälle huomiolle ovat jääneet empiiriset sovellukset, joissa tuodaan esille, kuinka yhteiskunnallisia valtasuhteita uusinnetaan tunteiden avulla (Kolehmainen \& Juvonen 2018, 3). Ruokahalujen tutkiminen on osoitus sukupuolentutkimuksen kentällä tehdyn teoreettisen tutkimustyön sovellusmahdollisuuksista yhteiskunnallisiin käytäntöihin. Artikkelissani tuon esille, kuinka sukupuolittuneita ruokailukäytäntöjä uusinnetaan esittämällä lihaproteiinit normaalina ja hyväksyttynä ja kasvisproteiinit vaihtoehtoisina ja kummeksuntaa herättävinä.

Tunteita määritellään Sara Ahmedin (2014) ja filosofi Lauren Berlantin (2011) näkemysten pohjalta. Molemmat ovat osallistuneet feminismin ja queer-teorian nykykeskusteluun tunteita käsittelevien tutkimuksiensa avulla. Ahmed (2014) tarkastelee sitä, kuinka julkiset puhetavat ja tarinat synnyttävät ja ylläpitävät tunteita, joiden avulla luodaan määritelmiä erilaisista ihmiskehoista.

Tämän tutkimuksen kannalta Ahmedin (2014) keskeisiä anteja on ymmärtää tunteet yhteiskunnallisiksi, historiallisiksi ja sellaisiksi, joihin julkinen keskustelu ja puhetavat vaikuttavat. Maskuliinisuuteen yhdistetty halu syödä lihaa on yksi tällainen puhetapa, joka ylläpitää tunteita liha- ja kasvisproteiinien eriarvoisuudesta. Berlant (2011) puolestaan osoittaa, kuinka yhteiskuntamme on täynnä erilaisia lupausten yhteenliittymiä, joiden pohjalta ihmiset ovat muodostaneet tapoja ylläpitää arkielämäänsä. Lihan syöminen on yksi tällainen lupaus, joihin talouskasvua korostavan yhteiskuntajärjestyksen näennäinen hyvinvointi on pohjautunut. Tämä on nähtävissä esimerkiksi siinä, että talouskasvun myötä lihankulutus kasvaa merkittävästi länsimaiden ulkopuolella (ks. Potts 2016).

Elämme monilajisessa maailmassa, jossa aistivat ja kokevat subjektit kohtaavat toisensa (Rose 2011, 49). Kertomus ihmislajin erityislaatuisuudesta on synnyttänyt tunteita, joiden perusteella ihmiset kokevat tarvetta hallita ja kontrolloida luontoa. On kuitenkin käynyt ilmeiseksi, että ihminen ei kykene hallitsemaan ihmistoiminnan seurauksia (Rose 2011, 48). Esitän monilajista empatiaa lähestymistavaksi, jonka avulla ammattikasvattajat ja ruokavalioitaan pohtivat kuluttajat voivat määritellä uudelleen suhdettaan elävään luontoon. Ilman elinkelpoista ja vastavuoroista monilajista yhteistyötä elämän edellytykset maapallolla heikkenevät tulevaisuudessa radikaalisti.

\section{TUNTEITA HERÄTTÄVÄT LIHA- JA KASVISPROTEIINIT}

Tunteet liikuttavat meitä ja se, kuinka liikutumme, pohjautuu aistielämyksistä tehtyihin tulkintoihin. Tunteemme ja tunne-elämyksemme ovat myös sidoksissa jo elettyihin tulkintoihin, jotka on tehty meidän edessämme (Ahmed 2014, 170). Yhdessä eletty ja koettu muodostavat kollektiivisen intuition, joka on samanaikaisesti sekä yksilöllinen että yhteisöllinen elämäntarina (Berlant 2011, 53).

Toisen maailmansodan jälkeiset muutokset teollistuneessa lihantuotannossa, maanviljelyssä ja eläinten jalostuksessa yhdistettynä valtavaan lihan kysyntään ovat synnyttäneet aikakauden, jota voidaan nimittää 'lihakulttuuriksi' (Potts 2016, 1). Feministi ja eläinoikeuksien puolustaja Carol Adams (2010, 241) esittää, että vallitsevat puhetavat hyväksyvät lihansyömisen, minkä myötä kuolleiden eläinten syömisestä on muodostunut hyväksytty, huomioimaton, naturalisoitu ja tukahdutettu käytäntö. Kasvisruoka ja kasvisruokailijat puolestaan saatetaan kokea lihakeskeisen elämäntavan uhaksi, jolloin kasvisruokailijat edustavat toiseutta, joka uhkaa totuttua elämäntyyliä (vrt. Ahmed 2014, 154). 
Suomessa kielteisimmin ekologisesti kestäviin ruokavalioihin suhtautuvat hyvin toimeentulevien miesten ryhmään kuuluvat, mikä ilmenee esimerkiksi haluttomuutena luopua punaisesta lihasta. Kasviperäisten ruokavalioiden suosio on suurinta alle 30-vuotiaiden ja yli 60-vuotiaiden parissa, kun taas pääkaupunkiseudulla asuvat suosivat kasviperäisiä tuotteita enemmän kuin maaseudulla asuvat. (Lehikoinen \& Salonen 2019.)

Vaikka vegaaniruokavaliot ovat kasvattaneet suosiotaan, maailmanlaajuinen lihankulutus on lisääntynyt tasaisesti. Joidenkin eläinten, kuten sikojen, syöminen on kuitenkin vähentynyt, kun taas siipikarjan syöminen on lisääntynyt. (Potts 2016; Patel \& Moore 2017.)

Liha linkittyy maskuliinisuuteen ja valtaan, minkä vuoksi vaihtoehtoisia ruokavalioita marginalisoidaan ja pilkataan (Calvert 2014). Historiallisesti metsästämällä hankittu liha ja erityisesti suurriista on ollut miesten hallinnoimaa toimintaa lukuisissa kulttuureissa. Metsästetty liha on ilmentänyt voimaa ja valtaa, jotka ovat olleet keskeisiä miehisyyden määrittäjiä. Liha on ollut rajallinen resurssi useissa kulttuureissa, minkä vuoksi tyypillisesti ainoastaan miehet ovat syöneet lihaa. (Rozin ym. 2012, 631.)

Kuluneiden vuosikymmenten aikana tasa-arvo lisääntynyt, ja vähemmistöjen oikeuksien tunnustaminen on osaltaan muuttanut asenneilmastoa, jossa sukupuolirooleja tuotetaan. Liikehdintää on ollut pois maskuliinisesta "perunat ja punainen liha" -ruokailutottumuksista kohti yhä eettisempää ja terveellisempää ruokaa sekä joissain tapauksissa kohti ei-länsimaalaista ruokaa. Muutos on synnyttänyt uudenlaisen diskursiivisen tilan, jossa pystytään määrittelemään uudelleen sitä, mitä miehisyydellä tarkoitetaan. (Wright 2015, 108.) Vaikka on olemassa edellytyksiä määritellä maskuliinisuutta uudella tavalla, moni mies saattaa vierastaa ajatusta liharuokaannoksista luopumisesta. Hegemonista maskuliinisuutta pidetään yleisesti ottaen normina, jolloin siitä poikkeaminen saatetaan kokea kummallisena ja vaikeana hyväksyä (Sumpter 2015).

Feministinen ajattelu tarkastelee miesten ja naisten välisiä suhteita mutta on samalla analyyttinen väline ihmisten ja muiden eläinten välisten yhteiskunnal- listen suhteiden ymmärtämiseen (Adams 2010, 9). Eläinten aseman uudelleen kirjoittamista voidaan pitää länsimaisen ajattelun suurimpana haasteena (Aaltola 2018,230). Ateriavalinnat ilmentävät ruokailijan ja muun eläinkunnan välistä suhdetta. Erot ruokalautasilla ja -haluissa ovat osa sitä identiteettituotantoa, jossa tunnistettujen erojen avulla minuutta tuotetaan ja ylläpidetään sosiaalisissa kohtaamisissa.

Filosofi ja gender-tutkija Judith Butler $(1987,9)$ toteaa, että halujen tyydyttäminen on erojen muutosta identiteetiksi. Tämä ilmenee käytännössä silloin, kun ihminen vahvistaa identiteettiään tiedostettujen ruokahalujen ohjaamien kulutusvalintojen avulla. Pelkkä yksilöllinen halu ei kuitenkaan selitä sitä, miksi lihaa kulutetaan yhä enemmän. Lihan kulutuksen kasvua selittää monimutkainen ja intensiivinen kapitalistinen maailmanjärjestys, joka on tuottanut edellytykset teolliselle teurastamiselle (Patel \& Moore 2017, 156).

Suhtautuminen erilaisiin ruokatapoihin ja -valioihin sisältää yleensä kulttuurisia puhetapoja. Yhdysvalloissa suhtautuminen naisten normeista poikkeaviin ruokavalioihin on synnyttänyt huolipuhetta naisten kehojen terveydestä, lasten vaarantamisesta ja uhasta koko kansakunnalle. Huolipuhe on ilmennyt suurten mediatalojen julkaisuissa, joissa suhtautuminen vegaaniruokavalioon on ollut kielteinen. (Wright 2015, 90.)

Mediaesityksien katsojia puhutellaan yksilöllisesti, minkä myötä katsotusta ja luetusta muodostuu henkilökohtainen katsojakokemus. Samalla mediaesityksiin sidotaan semanttisten, sosiaalisten ja yhteiskunnallisten arvojen ohella fantasia ja tunteet. (de Laurentis 1984, 8.) Huolipuheen myötä kasvisruoka saatetaan kokea epäilyttävänä tai vajavaisena, minkä vuoksi sitä ei välttämättä pidetä todellisena vaihtoehtona lihaproteiineille.

Mielikuvat ja tunnetilat liittyvät usein toisiinsa. Tunteilla on taianomainen taipumus kontrolloida maailmaa, ja kuvat tarjoavat mielikuvitukselle keinon kuvitella toisenlaisia maailmoja. Tämän vuoksi mielikuvitus tarvitsee kuvia ja mielikuvia pyrkimyksessään kuvitella maailma uudestaan. (Butler 1987, 115.) Mielikuvat, puhetavat ja mediaesitykset ylläpitävät ja synnyttävät tunteita, jotka osaltaan muo- 
JULKISESSA KESKUSTELUSSA

\section{KASVISRUOKA ESITET $\ddot{A} \ddot{A} N$}

\section{HIILINEUTRAALIMPANA}

\section{VAIHTOEHTONA}

LIHARUOALLE.

vaavat suhtautumista maailmaan. Jos lautasella oleva jalostetuote nähdään ainoastaan ruokana, jää huomaamatta se, että syömme jotakuta emmekä jotakin (Adams 2010, 48).

Julkinen keskustelu näyttäytyy usein niin, että kasvisproteiinit esitetään hiilineutraalimpana vaihtoehtona liharuoalle. Huomionarvoista on se, millä tavoin elintarvikkeet ja ruokavalioratkaisut esitetään, minkälaisin puhetavoin niitä myydään kuluttajille ja nähdäänkö ruokavaliot ekologisina, eettisinä, kulttuurisina, taloudellisina vai ravitsemuksellisina valintoina. Ruoka voi myös synnyttää elämyksiä ja mielihyvää. Nautintoa tavoittelevaa asennetta korostavat miehille suunnatut mainokset, joissa liharuoka-annoksia ihannoidaan rinnastamalla seksi, katseen kohteena oleva naiskeho ja liha (esim. Calvert 2014). Liharuokailu edustaa ruokanautintoa, kun taas kasvisruoka on epäilyttävää. Liharuoasta luopuminen saattaisi johtaa nautinnosta luopumiseen, koska kasvisruoka ei tarjoa samanlaista nautintoa kuin liharuoka.

Siirtyminen kasvisruokavalioon edellyttää samanaikaisesti luopumista ja uudenlaisen ruokavalion omaksumista - ehkä nämä ruokavalioon kohdistuvat muutosvaatimukset herättävät ristiriitaisia tunteita. Kasvisruoka saatetaan kokea pahanmakuiseksi tai hankalaksi, jos työpaikan lounasravintolassa ei ole kasvisruokavaihtoehtoa. Joissain sosiaalisissa verkostoissa kasvisruoka saattaa herättää kielteisiä tunteita, minkä vuoksi kasvisruokavaliota ei välttämättä koeta sosiaalisesti hyväksytyksi vaihtoehdoksi. Ajatus liharuosta luopumisesta ekologisista tai eettisistä syistä voidaan myös kokea vieraana. Tunteet kehittyvät ja nousevat pintaan vuorovaikutuksessa, minkä vuoksi ne ovat yhteisöllisiä (Ahmed 2014, 10). Ruokailutilanteet ovat täynnä kohtaamisia, joissa ruokailijat voi- vat kohdata toisiaan ja kokea uudenlaisia makuelämyksiä. Tunteemme ovat tulkintoja siitä, mitä koemme, mitä olemme kokeneet ja minkälaisia tulkintoja olemme todistaneet (Ahmed 2014, 171). Suhtautuminen ruokaan kehittyy kasvatuksen myötä, jolloin ruokailukokemuksien ansiosta kehittyy yksilöllinen tunneside erilaisiin ruokiin. Ruoka maistuu aina joltain, mutta kasvatus edistää yksilöllisen ruokasuhteen muodostumista.

Vaikuttaa siltä, että usein ruoasta käytävissä keskusteluissa on olennaisempaa se, minkälaisia tunteita ruoka herättää kuin se, minkälaisia seurauksia nykyisenlaisella ruokatuotannolla on planeetallemme. Eläinten kasvattaminen teuraaksi aiheuttaa ympäristövahinkoja esimerkiksi kasvavien metaanipäästöjen ja metsien hakkuun vuoksi. Lihatuotanto usein myös edellyttää eläinten elämistä ahdingossa. Jos se ahdinko ei kiinnosta tai ei usko ilmastonmuutokseen, liiallisen lihansyönnin negatiiviset terveysvaikutukset saattavat kannustaa vähentämään liharuokaa lautasella. (Despret 2016, 82.) Jotkut pitävät nykyisenlaista ruokatuotantoa eettisesti kestämättömänä, kun taas toiset kantavat huolta lihatuotannon ympäristövaikutuksista. Toiset eivät ole valmiita vähentämään liharuokailua, vaikka ruokavalio uhkaisi terveyttä.

Arjen ruokavalinnoissa huomionarvoista on se, ketkä valmistavat kodeissa ruokaa ja millä perusteella kotiruokavalinnat tehdään. Suomalaisten ruokailutottumuksia tutkittaessa on huomattu, että Suomessa keski-ikäisten miesten on vaikeinta luopua punaisen lihan syömisestä (Lehikoinen \& Salonen 2019). Ekologisesti nykyistä kestävämmän maailman puolesta toimivan kasvatustieteen tehtäväksi jää tällöin löytää keinoja synnyttää ekologisesti nykyistä kestävämpiä ruokahaluja niin koteihin kuin kouluruokaloihin ja lounasravintoloihin.

\section{KASVATUKSEN MIELENMAISEMAN MUUTOS}

Länsimaisen kuluttamisen ongelma ei ole ainoastaan se, mitä syömme vaan myös se, mitä emme syö. Merkittävä osa ruokaan liittyvistä ympäristöhaitoista syntyy ruokahävikistä. (ks. Schmidt \& Matthies 2018.) Leimallista nyky-yhteiskunnalle on kokemus, joka voidaan nimetä "ei ole väliä" -kokemukseksi. Tällöin 
oman toiminnan ja maailmanlaajuisten seurausten suhdetta ei nähdä merkityksellisenä. Tämä kokemus normalisoi epäoikeudenmukaisen maailmanjärjestyksen. (Värri 2018, 61.) Näkökulman laajentaminen saattaa auttaa löytämään sellaiset käsitteelliset työkalut, joiden avulla kasvatustiede voi haastaa arkisen "ei ole väliä" -kokemuksen. Nykyinen kasvatustieteellinen ajattelu ei tähän riitä, vaan kaivataan monitieteistä keskustelua ja analyysiä maailman tilasta sekä tavoista kohdata tulevaisuuden haasteet.

Eurooppalainen valistuksen projekti on ilmennyt universaalina modernisaationa, jota lukuisat postmodernistit ovat kritisoineet. Ekofeministinen näkökulma korostaa monimuotoisten kulttuurien ja ekosysteemien suojelemista, mikä on ehto elämän säilymiselle tällä planeetalla. (Shiva \& Mies 2014, 11.) Humanismi on myötävaikuttanut länsimaisten ajattelutapojen kehitykseen, jossa ei-länsimaalaiset on määritelty epäinhimillisesti. Radikaaleissa feministisissä ja jälkikolonialistisissa puheenvuoroissa esitetään uudenlaisia ja innovatiivisia näkemyksiä ihmisenä olemisen uudelleen määrittelyyn. (Braidotti 2013, 28.)

Alkuperäiskansojen kohtaama imperialismi juontaa juurensa eurooppalaiseen valistukseen. Valistus muodosti ideologiset edellytykset, jotka loivat pohjaa teolliselle vallankumoukselle, liberaalille filosofialle, tieteenalojen kehittymiselle ja julkisen koulutusjärjestelmän muodostumiselle. Alkuperäiskansoista muodostui kehittyvien tieteenalojen tutkimuskohteita, minkä myötä niitä alettiin mitata, kategorisoida ja luetteloida. Näin kuva alkuperäiskansoista välittyy niin eurooppalaisille kuin itseään etsiville alkuperäiskansojen jäsenille näiden historiallisten perinteiden avulla. (Smith 2012, 61.)

Kun eurooppalaiset "löysivät" Amerikan ja Afrikan alueet ja ryhtyivät tutkimaan niillä eläneitä kansoja ja ihmisiä, alkuperäiskansoja syytettiin kannibalismista. Alkuperäiskansojen leimaaminen raakalaismaisiksi oikeutti valkoisten kristittyjen heihin kohdistamat hyökkäykset ja orjuuttamisen. (Adams 2013, 213; Chen 2012, 40.) Rasismi tuottaa jakolinjoja ihmiskuntaan, minkä vuoksi ihonvärin perusteella voidaan riistää joidenkin ihmisryhmien ihmisarvoja ja kohdistaa ne järjestelmälliselle väkivallalle (Braidotti 2013, 47). Rasismia pidetään yllä, kun puhutaan lihasta yli- voimaisena proteiinin lähteenä. Eläinproteiinien ylivertaisuuden korostaminen vääristää niiden kulttuurien ruokahistoriaa, joissa proteiinien tarve on täytetty kasviperäisillä proteiineilla. (Adams 2013, 214.)

Jälkikolonialistisia näkemyksiä tarvitaan, jotta tieteentekijät voivat ylittää länsimaisen tieteen itselleen asettamat mielikuvarajat (Tsing 2015, 217). Valtaosa tieteenaloista ja tiedon tuotannosta pohjaa kulttuuriseen maailmaan, jossa toisenlaisia tietämisen tapoja pidetään merkityksettöminä. Tieteenalojen kehittyminen valistuksen, kolonialismin ja imperialismin aikakaudella tuottaa yhteisen historian, joka ilmenee nykyisyydessäkin. (Smith 2012, 68-69.) Vaikka suomalaisista oppikirjoista on siivottu pois räikeimmät kolonialismin jäänteet, niistä on yhä löydettävissä ajatus länsimaisesta ylivertaisuuden hegemoniasta (Mikander 2016,78). Kasvatusalan ammattilaiset voivat tiedostamattaan pitää yllä eurosentrisiä ajattelutapoja, jotka puolestaan vahvistavat oppilaiden tunne- ja ajatusmaailmoja eurooppalaisesta erityislaatuisuudesta.

Ajattelutapojen uudistamiseen tarvitaan halua kuunnella niitä, jotka elävät ja hahmottavat maailmankaikkeuden ja ihmisten aseman maailmassa toisella tavalla kuin länsimaisessa kulttuuripiirissä (Pilisuk \& Joy 2014, 142). Lukuisat esimodernit maailmankatsomukset ja tavat olla poikkeavat toisistaan. Niiden yhteisenä piirteenä pidetään luonnon ja elämän välistä yhteyttä, joka eroaa modernistisista ajattelutavoista (Kincheloe 2011a, 203-204).

Australian alkuperäiskansojen maailmankatsomuksessa kuolema ja elämä kuuluvat yhteen, mutta tappamisen tai tappamisen välttämisen sijaan keskeistä on eettinen velvollisuus kantaa vastuu, joka on sidottu aikaan ja paikkaan (Rose 2011, 19). Kaivataan enemmän yhteiskunnallista keskustelua siitä, millä tavoin perustelemme tappamisen ruoaksi, milloin on välttämätöntä tappaa, voidaanko tappamista välttää ja onko teollinen eläinten kasvatus ja teurastus vastuullista ekologisesti tai eettisesti. Vaikka yhtä lailla alkuperäiskansat ja useat muut ihmisjoukot ovat tappaneet eläimiä ruoaksi, nyky-yhteiskunnassa harva metsästää itse ruokansa tai teurastaa kasvattamansa eläimen ravinnokseen. Markkinaehtoisessa maailmassa lihan hankinta on useimmiten ostostapahtuma, kun taas alkuperäiskansojen harjoittamissa 
EL $\ddot{A}$ ÄNMUOTOMME KAIPAA

VALISTUKSEN, KAPITALISMIN

JA MODERNISAATION

PERINTEEST $\ddot{A}$ POIKKEAVAA

TARINAA.

metsästyskulttuureissa lihan hankinnassa tapettava eläin kohdataan kokonaisena eikä ainoastaan valmiiksi jauhettuna tai paloiteltuna ruhon osana.

Eläimen syöminen merkitsee sitä, että joku on tapettu sen vuoksi, että toinen saa syödäkseen (Rose 2011, 26). Ruoaksi tapettu eläin on tapettu jossain. Esimerkiksi teurastamot ovat kadonneet kaupungeista, minkä vuoksi eläinten kuoleminen tapahtuu jossain muualla (Despret 2016, 83). Liharuoka ja siten kuolleet eläimet ovat läsnä miltei joka päivä kouluruokailuissa, mutta en ole ikinä kuullut koulussa puhuttavan siitä, missä ja miten eläimet ovat eläneet ja kuolleet. Kuolema ja kuolemisen käsittely osana ympäristökasvatusta saattaa sisältää lukuisia potentiaalisia tunteellisia, kognitiivisia ja moraalisia mahdollisuuksia (Russell 2017, 87).

Huomionarvoista on tarkastella tarinoita, jotka tuottavat tarinoita, ja sitä, minkälaisin käsittein tuotetaan käsitteitä. Matemaattisesti, visuaalisesti ja narratiivisesti sillä on merkitystä, minkälaiset järjestelmät järjestelevät järjestelmiä. (Haraway 2016, 101.) Kuluttajuuteen sisältyy tarinoita, joita ihmiset jakavat keskenään ja täten vahvistavat ajatusta kulutuskeskeisyydestä. Tarinat myös synnyttävät tunteita, jotka puolestaan ohjaavat ihmisten tapoja määritellä itseään ja toisia ihmisiä (Ahmed 2014, 43). Ne ovat merkityksellisiä maailmasuhteen muovaajia, minkä vuoksi on syytä etsiä ja jakaa ekologisesti yhä kestävämpiä tarinoita. Samalla kaivataan avarakatseisuutta ja herkkyyttä, jotta voidaan etsiä uudenlaisia suhtautumistapoja elämään maapallolla.

Kuuntelemalla alkuperäiskansojen kertomuksia tavoista hahmottaa maailmaa avartuu edellytyksiä oppia inhimillisestä moninaisuudesta (Kincheloe \& Steinberg 2008). Australian alkuperäiskansoilta voi- daan omaksua ajatus siitä, että maasta huolehtiminen on elävä kokonaisuus, jossa mennyt, nykyisyys ja tuleva kohtaavat ja muodostavat näin lajien välisen hoivasuhteen (Rose 2011, 27). Alkuperäiskansat mukautuivat vallitseviin luonnonoloihin eivätkä juuri muuttaneet ympäristöjään. Ne elivät yhdessä puiden, meren elävien ja luonnon antimien parissa. Tuhansia vuosia alkuperäiskansat olivat eläneet harmonisessa suhteessa luonnon kanssa. Eurooppalaisten saapuminen saattoi päätökseen niiden elämäntavat. (Pilisuk \& Joy 2014, 141.)

Pyrkimys ei ole romantisoida alkuperäiskansojen elämää vaan tarjota vaihtoehtoja hahmottaa ihmisyyttä osana kestävää luontosuhdetta. Länsimaisen kulttuuripiirin ulkopuolelta tulevia kuuntelemalla voidaan löytää eettisesti yhä kestävämpiä tarinoita, jotka puolestaan myötävaikuttavat uusien ekologisesti ja eettisesti kestävämpien elämäntarinoiden kehittymiseen. Elämänmuotomme kaipaa valistuksen, kapitalismin ja modernisaation perinteestä poikkeavaa tarinaa, jonka avulla voidaan synnyttää uusia, yhä kestävämpiä ekologisia, sosiaalisia, kulttuurisia ja taloudellisia tarinoita olemassaolostamme, sillä muuten kulutamme loppuun kertakäyttöisen planeettamme. Vähentämällä merkittävästi lihaproteiinien käyttöä otetaan ensiaskeleita ekologisesti nykyistä kestävämpään ruokavalioon.

\section{MONILAJINEN EMPATIA}

Monilajinen empatia ammentaa kertomuksista, joissa elämä maapallolla on täynnä vastavuoroisia riippuvuussuhteita, ennakoimattomuutta, haurautta ja toistuvuutta. Ennen kaikkea se on vaarassa päättyä sukupuuttoon. Monilajinen empatia pohjautuu osaltaan lajikatoa käsitteleviin tutkimuksiin. Esimerkiksi Thom van Dooren (2014) kuvaa kirjoituksissaan, kuinka ihmistoiminta saattaa lintulajeja sukupuuton partaalle. Ajatus ihmisen erityislaatuisuudesta ja ihmiset sekä eläimet erotteleva dualistinen ajattelu estävät meitä liikuttumasta lajien massakuolemista (van Dooren 2014, 18). Monilajinen empatia kannustaa näkemään, kuuntelemaan ja kokemaan maailman, jossa kaikki elämä on merkityksellistä ja tärkeää.

Ajatus ihmislajin erityislaatuisuudesta sokeuttaa meidät siltä tosiasialta, että ihmisluonto on monilajis- 
ten verkkojen yhteistyön tulosta (Tsing 2012, 144). Näyttää myös siltä, että osa inhimillisinä pidetyistä tunteista on omittu koskemaan ainoastaan ihmistoimintaa. Tuoreimpien tutkimustulosten mukaan empatia on levinnyt laajalla eläinkuntaan, mikä näkyy eläinten kykynä auttaa toisiaan silloinkin, kun se tuottaa yksilölle itselleen haittaa. (Aaltola \& Keto 2017, 247-248.)

Empatian voidaan ajatella sisältävän monenlaisia muotoja yksinkertaisesta toisen tunnetilan tunnistamisesta monimutkaisiin tapoihin ymmärtää ja kohdistaa apua (van Dooren 2014, 135-136). Luonnossa on havaittu, että empatiaa ilmenee simpanssien käyttäytymisessä, jossa on nähtävissä pyyteettömyyttä ja epäitsekkyyttä (de Waal 2012, 128). Monilajinen empatia on suhtautumistapa monimuotoiseen elämään maapallolla. Maapallon elinvoiman ylläpitäminen edellyttää ihmistoiminnan saattamista ekologisesti, taloudellisesti, kulttuurisesti ja sosiaalisesti yhä vastuullisemmaksi.

Kristillinen kosmologia, kapitalismi ja kolonialismi ovat käsitteellistäneet poliittisesti dominoivan maailmankatsomuksen, jonka avulla on määritelty hierarkioita olioiden tietoisuuksien, elollisuuksien, kyvykkyyksien, toimijuuksien ja liikkuvuuksien välille. Nämä elämää arvottavat käsitteet ovat synnyttäneet tunteiden hierarkioita, joissa määräytyy se, ketkä voivat liikuttaa toisia. (Chen 2012, 29-30.)

Länsimainen koti on täynnä riippuvuussuhteita ja intiimiyttä, ja samalla se on asettanut rakkaudelle rajat. Kodin sisällä rakkaus muita eläimiä kohtaan on odotettua, mutta rakkaus lemmikkejä kohtaan ei leviä kodin seinien ulkopuolisiin eliöihin. (Tsing 2012, 150.) Rakkautta on luontevaa kokea lemmikkejä kohtaan, kun taas villieläimet saattavat herättää toisenlaisia tunteita. Olennaista on huomioida se, minkälaisia tunteita eläinten kohtaamiset herättävät. Tunteet muovautuvat vuorovaikutuksessa sekä jo eletyn kanssa että subjektin ja objektin välillä, minkä vuoksi ne eivät ole valmiina vaan elävät kohtaamisissa (Ahmed 2014, 5).

Ihminen voi kohdata elämänsä aikana hyvin eri asemassa eläviä eläimiä, kuten tuotantoeläimiä, lemmikkieläimiä tai luonnossa eläviä eläimiä. Kohtaamiset metsässä elävän hirven tai naapurin uuden lemmikin kanssa todennäköisesti herättävät erilaisia tunteita. Samalla kohtaaminen kasvokkain on eettis- tä, koska tällöin vaaditaan kykyä tunnistaa toinen ja vastata tämän viesteihin (Rose 2011, 12). Kasvokkain kohtaaminen on filosofi Emmanuel Levinasin (1996, 73) esittämä ajatus siitä, että toisen kasvojen kohtaaminen on eettistä, jolloin ei keskitytä kasvojen ulkoisiin piirteisiin, vaan kohdataan toinen objektin sijaan subjektina. Tarvitaan enemmän pohdintaa ja keskustelua siitä, millä tavoin kohtaamme elämän maapallolla, minkälaisia tunteita eläimet meissä herättävät, keiden elämää arvostetaan ja keiden kuolema koetaan välttämättömänä osana ruokateollisuutta.

Monilajinen empatia kumpuaa siitä ajatuksesta, että ihmisen hyvinvointi ja selviytyminen maapallolla edellyttää kanssaeläjiä, jotka luovat edellytykset ihmiskunnan olemassaololle maapallolla. Yhteistyö käynnistyy jo solutasolla, sillä 90 prosenttia ihmisen soluista on täynnä genomeja bakteereilta, sieniltä, alkueliöiltä ja muilta olioilta (Haraway 2008, 3). Vuorovaikutuksessa elävät lajit muovaavat yhdessä toisiaan monimuotoisessa yhteistoiminnassa. Tässä vuorovaikutussuhteessa herkkyys ja toisen kunnioitus muodostavat epäsymmetrisen suhteen perustukset elämälle ja kuolemalle sekä hoivalle ja tappamiselle. (Haraway 2008, 42.)

Yhteistyö tai lajien välinen vuorovaikutus sisältää myös ennakoimattomuutta ja riskejä, mikä voi ilmetä syöpäsolujen muodostumisena tai lajista toiseen siirtyvinä viruksina. Olennaista on yhteistyön merkittävyyden ohella tiedostaa riskejä, jotka liittyvät lajien välisiin kontakteihin. Päätösten ja muutoksien aika on nyt, minkä vuoksi meidän on opeteltava olemaan vaarattomampia kuin tähän asti olemme olleet sekä ymmärtämään elämän ja kuoleman merkitys monilajisessa symbioottisessa ja vastavuoroisessa yhteistyön maailmassa (Haraway 2016, 98).

Muutos vaatii halukkuutta vuoropuheluun ja vastuunkantoon sekä valintaa kohtaamiselle ja herkkyydelle, jolloin katsotaan kohti eikä käännetä katsetta pois (Rose 2011, 4). Usein on helpompaa vältellä epämukavia tosiasioita kuin kohdata vastuukysymyksiä ekologisesti kestämättömän kuluttamisen aiheuttamista moninaisista ekologisista ja taloudellisista seurauksista. Huomionarvoista on se, minkälaisten tarinoiden parissa ihmiset kasvavat kohtamaan maailmaa. Jatkuvan kilpailun eetoksen sijaan elämää voi esimerkiksi kuvailla symbioosina, joka on täynnä em- 
Monilajinen EMPATia

EDELLYTTÄ̈̈ KYKY ̈̈

KUUNNELLA JA OPPIA

NÄKEMÄ̈̈N MAAILMA TOISIN.

patiaa sekä vastavuoroisia riippuvuussuhteita ja joka vahvistaa organismien välisiä suhteita ja toimii samalla itsekkyyden vähentäjänä (Aaltola \& Keto 2017, 240). Kasvattamalla uteliaisuutta muihin kanssaeläjiin pystytään oppimaan uutta ja kasvattamaan vastuuta (Haraway 2008, 287). Vuorovaikutuksessa tunne ja tieto kietoutuvat yhteen niin yhteiskunnallisessa retoriikassa kuin kasvatus- ja opetustyössä. Empatiakasvatuksen taustalla on ajatus, että empatiaa, kuten muitakin tunteita, voidaan kultivoida. Empatian avulla pystytään luomaan kasvatusta, jossa kaikki elämä on ontologisesti tasa-arvoista. (Värri 2018, 81.)

Monilajinen empatia edellyttää kykyä kuunnella ja oppia näkemään maailma toisin. Monilajisen maailman pelastamista sukupuutoilta eivät helpota yksinkertaistetut ajattelutavat, joissa luonto ja kulttuuri sekä ihminen ja ei-inhimillinen nähdään erillään (van Dooren 2014, 147). Kädellisten käyttäytymistä koskevat tutkimukset ovat luoneet pohjaa humanismia kritisoivalle ajattelulle, koska empatia korostaa sitä, että järjen sijaan tunteiden merkitys on huomioitava tietoisuutta tarkasteltaessa (Braidotti 2013, 78). Monilajisessa empatiassa kannustetaan epäitsekkyyteen, sillä ilman luopumista esimerkiksi normaalina koetusta liharuoasta ei todennäköisesti saavuteta ilmaston muutoksen hillitsemiseksi asetettuja tavoitteita.

Niin ihmislajin kuin kaikkien muidenkin lajien säilyminen vaatii elinkelpoista yhteistyötä. Yhdessä selviytyminen on samalla epämääräistä itsen ja toisen muutosta. Me muutumme tekemällä yhteistyötä sekä oman että muiden lajien kanssa. Se on kykyä ratkaista pulmia eroavaisuuksista huolimatta. (Tsing 2015, 28-29.) Yhteistyö saattaa olla hankalaa sellaisten lajien kanssa, jotka herättävät ihmisissä kielteisiä tunteita. Ihmisten ja eläinten historiallisia suhteita yhdysvaltalaisissa kaupungeissa tutkinut Dawn Biehler (2013) kuvaa, kuinka rottia on yritetty tuhota monin eri tavoin kaupungeista. Kaupungeista on muodostunut elinympäristöjä lajeille, jotka ihminen haluaa saada tuhotuksi. Joka tapauksessa näiden lajien, kuten rottien, olemassaolo on seurausta ihmistoiminnasta, jolloin eläinten ja ihmisten toiminta on sidottu yhteen.

Elämä maapallolla on verkottunutta ja täynnä lukemattomia ennakoimattomia vuorovaikutussuhteita ja seurauksia. Eräs seuraus teknologisen kehityksen suomista mahdollisuuksista kontrolloida ei-toivottua luontoa oli toisen maailmansodan jälkeinen hyönteismyrkky diklooridifenyylitrikloorietaanin (DDT) käyttö. Rachel Carsonin vuonna 1962 julkaisema kirja Silent Spring osoitti kuitenkin sen, että DDT mahdollisesti myrkytti ihmisiä, villieläimiä ja luontoa (Biehler 2013, 10; Connell \& Pearse 2014, 103). Pyrkimykset hallita ja tappaa hyönteismyrkkyjen avulla aiheuttivat lopulta uhan ihmiselämälle. Jaetussa maailmassa ihmistoiminta saattaa aiheuttaa ennakoimattomia seurauksia, minkä myötä elämäntavat ja elämän edellytykset voivat vaarantua.

Uhanalaisten lajien olisi syytä synnyttää vastuuntuntoa tästä jaetusta maailmasta, joka on täynnä evolutiivisia, ekologisia ja tunteellisia kytköksiä ja vastuita (van Dooren 2014, 147). Lihaproteiinien käytön vähentäminen on yksi tapa kantaa vastuuta nykyisyydestä ja tulevaisuudesta, jolloin etsitään ekologisesti kestävämpiä ruokavalioita. Pohjimmiltaan monilajisuuden idea pohjautuu ajatukseen luopua ihmiskeskeisyyttä korostavasta ajattelusta (Tsing 2015, 162). Käytännössä tämä tarkoittaa kasvua yhä holistisempaan maailmasuhteeseen, jossa kannetaan huolta ja toimitaan maapallon elinkelpoisuuden puolesta. Kasvatus kaipaa päämääräkseen sellaisia tunteita, tietoja, asenteita ja kertomuksia, jotka kannustavat näkemään ja tuntemaan maailman verkottuneen haurauden. Parhaimmillaan empatia voi auttaa pois itsekeskeisyydestä. (Aaltola \& Keto 2017, 22.) Monilajiseen empatiaan sisältyy arvostus kaikkeen elämään maapallolla, koska vastavuoroisessa maailmassa hyvinvointi ja elämän edellytykset muovautuvat vuorovaikutuksessa.

\section{POHDINTA}

Artikkelissani olen tuonut esille lihaproteiinien synnyttämiä tunteita ja syitä liharuoan suosioon. Liharuoan suosiota on avattu historiallisten, aatteellisten, taloudel- 
listen ja lihaan liitettyjen mielikuvien avulla. Samalla esille on noussut se, että elämä maapallolla on täynnä yhteen kietoutuneita monilajisia siteitä, jotka synnyttävät elämää ja kuolemaa maapallolla. Monilajinen empatia kannustaa näkemään ne verkottuneet kokonaisuudet, johon yksittäiset kulutustottumukset liittyvät. Samalla tavoin koko kapitalistinen ruoantuotantojärjestelmä on täynnä ekologisia epävarmuustekijöitä, joita ihminen ei voi hallita. Esimerkiksi antropologi Anna Tsingin etnografisessa tutkimuksessa kuvataan, kuinka japanilaisten tuoksuvalmuska-sienen keräilijät ovat osa kapitalistista talousjärjestelmää. Raaka-aineiden rajallisuus asettaa myös rajat kapitalismin toimintakyvylle. (Tsing 2015, 63-64.)

Ruoka-aineet tulevat aina jostakin, ja niiden päätyminen lautaselle edellyttää lukuisia ekologisia, sosiaalisia ja taloudellisia kytköksiä ja verkostoja. Yhtä lailla kaikki ruokatuotanto voi synnyttää erilaisia eitoivottuja ekologisia, sosiaalisia tai taloudellisia seurauksia sekä paikallisesti että maailmanlaajuisesti. Siirtyminen kasvisruokavalioon ei välttämättä synnytä nykyistä kestävämpää ruoantuotantojärjestelmää, vaan on syytä tarkastella koko maailmanlaajuista ruokatuotantoa ekologisista, eettisistä, taloudellisista ja sosiaalisista näkökulmista.

Ihmiskeskeisyyttä korostavat ajattelutavat ovat syntyneet ajatuksesta ihmisen ja luonnon välisestä kahtiajaosta. Olen purkanut tätä kaksijakoisuutta tässä artikkelissa hyödyntäen feministisiä, jälkikolo- nialistisia ja eläintutkimuksellisia näkökulmia. Monilajisessa empatiassa yhdistyvät ajatukset monilajisuuden tärkeydestä maapallon elinvoimaisuudelle ja empatiasta epäitsekkääseen käytökseen kannustajana. Se yllyttää kantamaan huolta maapallon elämän edellytyksistä, mikä merkitsee uudenlaista hoivaa, vastuuta ja kestävämpiä elintapoja.

Monilajinen empatia pyrkii vastaamaan kriittistä pedagogiikkaa suomeksi julkaisseen Juha Suorannan $(2005,126)$ esittämään tavoitteeseen teoriasta, jossa painotetaan sekä yhteiskunnallisia rakenteita että yksilöllistä toimintaa. Sen ohjaamana ihminen tiedostaa kulutusvalintojensa seuraukset kanssaeläjiin, ja tällöin kuluttaja osaa tarkastella kulutusvalintojensa seurauksia eikä keskity henkilökohtaisiin mieltymyksiinsä. Monilajisen empatian avulla ihmiset hahmottavat elämän ja kuoleman perustuvan maapallolla monimuotoisiin ja -mutkaisiin verkostoihin. Artikkelillani pyrin synnyttämään itsekriittistä pohdintaa siitä, mikä on kasvatustieteen merkitys ja vastuu silloin, kun tavoitellaan ekologisesti, taloudellisesti, sosiaalisesti, kulttuurisesti ja eettisesti kestävämpää tulevaisuutta.

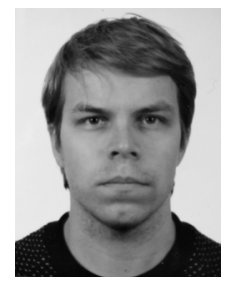

MIKKO ROSENBERG

KM, tohtorikoulutettava

kasvatustieteiden ja

kulttuurin tiedekunta

Tampereen yliopisto

(D) https://orcid.org/0000-00019993-9015

\section{LÄHTEET}

Aaltola, E. (2018). Eläimet yhteiskunnassa. Teoksessa J. Räikkä \& E. Aaltola (toim). Yhteiskuntafilosofia. Helsinki: Unipress, 225-242.

Aaltola, E. \& Keto, S. (2017). Empatia: myötäelämisen tiede. Helsinki: Into.

Adams, C. (2010). The Sexual Politics of Meat: A Feminist-Vegetarian Critical Theory. New York: Continuum.

Adams, C. (2013). Lihan sukupuolipolitiikka. Teoksessa E. Aaltola (toim). Johdatus eläinfilosofiaan. Helsinki: Gaudeamus, 206-227.

Ahmed, S. (2014). The Cultural Politics of Emotion, Second Edition. Edinburgh: Edinburgh University Press.

Berlant, L. (2011). Cruel Optimism. Durham (N.C.): Duke University Press.
Biehler, D. (2013). Pests in the: City Flies, Bedbugs, Cockroaches, and Rats. Seattle: University of Washington Press.

Braidotti, R. (2013). The Posthuman. Cambridge: Polity Press.

Butler, J. (1987). Subjects of Desire: Hegelian Reflections in Twentieth-Century France. New York: Columbia University Press.

Calvert, A. (2014). You are what you (M)eat: Explorations of meat-eating, masculinity and masquerade. Journal of International Women's Studies 16(1), 18-33.

Chen, M. Y. (2012). Animacies: Biopolitics, Racial Mattering, and Queer Affect. Durham, NC: Duke University Press. 
Connell, R. W. \& Pearse, R. (2014). Gender: In World Perspective. Cambridge: Polity.

Despret, V. (2016). What Would Animals Say If We Asked the Right Questions? Minneapolis: University of Minnesota Press.

Dooren, van, T. (2014). Flight Ways: Life and Loss at the Edge of Extinction. New York: Columbia University Press.

Giroux, H. (1989). Schooling as a form of cultural politics: Toward a pedagogy of and for difference. Teoksessa P. McLaren \& H. Giroux (toim.) Critical pedagogy, the state, and cultural struggle. Albany: State University of New York Press, 125-151.

Haraway, D. (1990). Primate Visions: Gender, Race, and Nature in the World of Modern Science. London: Verso.

Haraway, D. J. (2016). Staying with the Trouble: Making Kin in the Chthulucene. Durham: Duke University Press.

Haraway, D. J. (2008). When Species Meet. Minneapolis: University of Minnesota Press.

Hedenus, F., Wirsenius, S. \& Johansson, D. J. (2014). The importance of reduced meat and dairy consumption for meeting stringent climate change targets. Climatic Change 124(1-2), 79-91.

Kolehmainen, M. \& Juvonen, T. (2018). Introduction: Thinking with and through affective inequalities. Teoksessa M. Kolehmainen \& T. Juvonen (toim.) Affective Inequalities in Intimate Relationships. London: Routledge, 1-15.

Kincheloe, J. L. (2011a). Critical ontology. Teoksessa K. Hayes, S. Steinberg, \& K. Tobin (toim.) Key works in critical pedagogy. Rotterdam: Sense Publishers, 201-217.

Kincheloe, J. L. (2011b). Critical ontology and indigenous ways of being: Forging a postcolonial curriculum. Teoksessa K. Hayes, S. Steinberg \& K. Tobin (toim.) Key works in critical pedagogy. Rotterdam: Sense Publishers, 333-349.

Kincheloe, J. L. \& Steinberg, S. R. (2008). Indigenous knowledges in education: Complexities, dangers, and profound benefits. Teoksessa N. K. Denzin, Y. S. Lincoln, \& L. T. Smith (toim.) Handbook of critical and indigenous methodologies. Los Angeles: Sage Publications, 135-156.

Laurentis, de, T. (1984). Alice Doesn't: Feminism, Semiotics, Cinema. Bloomington: Indiana University Press.

Lehikoinen, E. \& Salonen, A. (2019). Food preferences in Finland: Sustainable diets and their differences between groups. Sustainability 11(5), 1259. DOI: https://doi:10.3390/su11051259

Levinas, E. (1996). Etiikka ja äärettömyys: keskusteluja Philippe Nemon kanssa: Toisen jälki. Helsinki: Gaudeamus.

Mikander, P. (2016). Westerners and Others in Finnish School Textbooks. Helsinki: University of Helsinki.

Patel, R. \& Moore, J. W. (2017). A History of the World in
Seven Cheap Things: A Guide to Capitalism, Nature, and the Future of the Planet. California: University of California Press.

Pilisuk, M., \& Joy, M. (2014). Humanistic psychology and ecology. Teoksessa J. F. T. Bugental, J. F. Pierson \& K. J. Schneider (toim.) The Handbook of humanistic psychology: Theory, research, and practice. California: Sage Publications, 135-148.

Potts, A. (2016) What is meat culture? Teoksessa A. Potts (toim.) Meat culture. Leiden: Brill, 1-30.

Rose, D. B. (2011). Wild Dog Dreaming: Love and Extinction. Charlottesville: University of Virginia Press.

Rozin, P., Hormes, J. M., Faith, M. S. \& Wansink, B. (2012). Is meat male? A quantitative multimethod framework to establish metaphoric relationships. Journal of Consumer Research 39(3), 629-643.

Russell, J. (2017). "Everything has to die one day:" children's explorations of the meanings of death in human-animal-nature relationships. Environmental Education Research, 23(1), 75-90. DOI: https://doi.or g/10.1080/13504622.2016.1144175.

Schmidt, K. \& Matthies, E. (2018). Where to start fighting the food waste problem? Identifying most promising entry points for intervention programs to reduce household food waste and overconsumption of food. Resources, Conservation \& Recycling 139, 1-14.

Shiva, V. \& Mies, M. (2014). Ecofeminism. New York: Zed Books.

Sumpter, K. C. (2015). Masculinity and meat consumption: An analysis through the theoretical lens of hegemonic masculinity and alternative masculinity theories. Sociology Compass 9(2), 104-114.

Suoranta, J. \& Ryynänen, S. (2014). Taisteleva tutkimus. Helsinki: Into.

Suoranta, J. (2005). Radikaali kasvatus: kohti kasvatuksen poliittista sosiologiaa. Helsinki: Gaudeamus.

Smith, L. T. (2012). Decolonizing Methodologies: Research and Indigenous Peoples. London: Zed Books.

Tsing, A. (2012). Unruly Edges: Mushrooms as companion species for Donna Haraway. Environmental Humanities 1(1), 141-154.

Tsing, A. L. (2015). The Mushroom at the End of the World: On the Possibility of Life in Capitalist Ruins. Princeton: Princeton University Press.

Värri, V. (2018). Kasvatus ekokriisin aikakaudella. Tampere: Vastapaino.

Waal, de, F. B. (2012). A bottom-up view of empathy. Teoksessa de Waal, F. B. \& P. F. E. Ferrari (toim.) The primate mind: Built to connect with other minds. Cambridge: Harvard University Press, 121-138.

Wright, L. (2015). The Vegan Studies project: Food, Animals, and Gender in the Age of Terror. Athens: University of Georgia Press. 